\title{
Heavy metal contamination of soil in mechanic workshops
}

\author{
Alewo Opuada AMEH ${ }^{1 *}$, Ibrahim Ali MOHAMMED-DABO ${ }^{2}$, Sani IBRAHIM ${ }^{3}$, \\ Joseph Baba AMEH ${ }^{4}$ and Josephine Onyama ODENGLE ${ }^{5}$ \\ ${ }^{1,2}$ Department of Chemical Engineering, Ahmadu Bello University, Zaria, Nigeria. \\ ${ }^{3}$ Department of Biochemistry, Ahmadu Bello University, Zaria, Nigeria. \\ ${ }^{4}$ Department of Microbiology, Ahmadu Bello University, Zaria, Nigeria. \\ ${ }^{5}$ Iya Abubakar Computer Center, Ahmadu Bello University, Zaria, Nigeria. \\ ${ }^{*}$ Corresponding author, E-mail: alewooameh@yahoo.com
}

\begin{abstract}
The distribution of metal in soil from mechanic workshops around Zaria, Nigeria (Latitude: $11^{\circ} 4^{\prime} 0 \mathrm{~N}$, Longitude: $7^{\circ} 42^{\prime} 0 \mathrm{E}$ ) was studied. The types of mechanic workshops considered were motorcycle, motorcar, truck/lorries and generator set. The soils were sampled in August 2010. The results indicated that there was an increase in the metal content of soil in all types of mechanic workshops. The heavy metal (nickel, copper, zinc, lead and arsenic) content of the soil was compared with recommended limits. The percentage composition of some of the heavy metals, in many of the samples, were found to be in excess of the considered set limit, particularly for lead for which the percentage of soil samples analyzed from motorcycle, motorcar, truck/lories and generator set mechanic workshops in excess of the considered recommended set limit was found to be $88.89,100,100$ and $100 \%$ respectively. $11.1 \%$ of all the samples analyzed were found to contain arsenic in excess of recommended limit. Statistical analysis of the heavy metal content (one-way analysis of variance) indicated that the $\mathrm{Zn}$ and $\mathrm{Pb}$ contents of soil from mechanic workshops were not functions of the workshop type $(\mathrm{P}>0.05)$ but the nickel and copper contents were found to be dependent on workshop type $(\mathrm{P}<0.05)$. (C) 2011 International Formulae Group. All rights reserved.
\end{abstract}

Keywords: Elemental analysis, Heavy metals, Mechanic workshop, Soil, Zaria.

\section{INTRODUCTION}

Soil is a crucial component of rural and urban environments, and in both places land management is the key to soil quality. Heavy metals are considered to be one of the main pollutants in the environment since they have a significant effect on its ecological quality (Sastre et al., 2002). Expanding interest in the field of heavy metal research is associated with an increasing world production of metals and their common usage in the past century and, consequently, with their increasing emissions into the environment. This has resulted in a growing hazard to human health posed by elevated metal concentrations in the air, water and food (Weber, 2004). The problem with heavy metals is their persistence, making it impossible to eliminate them from the environment (Sieghardt et al., 2005). Studies have shown that urban soils contain higher levels of heavy metals relative to the natural background levels ( $\mathrm{Li}$ et al., 
2001; Madrid et al., 2002). Though naturally present in relatively low concentrations, in recent years a number of anthropogenic sources such as emissions of industrial plants, vehicle exhausts, thermal power stations and commercial product waste, and the use of synthetic products (e.g. pesticides, paints, batteries, industrial waste, and land application of industrial or domestic sludge) have made notable contributions to the increase of metal concentrations in urban and agricultural soils (Li et al., 2001; Granero and Domingo, 2002; Ljung et al., 2006; Adelekan and Abegunde, 2011).

The heavy metal content of urban soils may influence public health via direct contact with contaminated dust or soil or by inhalation (Sieghardt et al., 2005). Children are the most sensitive target group of exposure (SanchezCamazano et al., 1994; Mielke et al., 1998; Granero and Domingo, 2002) due to their higher sensitivity, as well as characteristic behaviors (outdoor activities, hand-mouth activity, deficient hygienic habits, etc). Metals may be harmful to humans through ingestion of edible plants containing metals (through normal uptake), ingestion of plants splashed with contaminated soil or by accidental direct ingestion of soil usually by children. Breathing dust coming from soil may also pose a health risk. Metals of concern are arsenic (As), cadmium (Cd), chromium $(\mathrm{Cr})$, copper $(\mathrm{Cu})$, lead $(\mathrm{Pb})$, nickel $(\mathrm{Ni})$, selenium (Se), cobalt (Co), Manganese (Mn) and zinc (Zn) (Adelekan and Abegunde, 2011). Exposure to heavy metals is normally chronic (exposure over a long period of time), due to food chain transfer. Acute (immediate) poisoning from heavy metals is rare through ingestion or dermal contact, but is possible. Chronic problems associated with long-term heavy metal exposures are: lead - mental lapse, cadmium - affects kidney, liver, and gastrointestinal tract, arsenic - skin poisoning, affects kidneys and central nervous system (Adelekan and Abegunde, 2011). Some of the non-essential heavy metals have a stimulating or inducing effect when they are applied at very low concentration ("low concentration stressors"). For example, $\mathrm{Cd}$ has some stimulating effects in barley seedlings as well as $\mathrm{Pb}$ and $\mathrm{Ti}$ in detached barley leaves (Nyitrai et al., 2007; Kovacs et al., 2009). Cu and $\mathrm{Zn}$ are essential plant micronutrients. At high levels of concentration however, they may be toxic to plants (Vespa et al., 2010). Some trace elements e.g. $\mathrm{Co}, \mathrm{Cu}, \mathrm{Fe}, \mathrm{Mn}, \mathrm{Mo}$, $\mathrm{Ni}$ and $\mathrm{Zn}$ have essential functions in plant cells, only when the internal concentration exceeds a certain threshold do they exert toxic effects and then are commonly named heavy metals (Appenroth, 2010). Micronutrients are essential for biosynthesis and function of nucleic acids, growth substances, chlorophyll, secondary metabolites and carbohydrates as well as for stress resistance. The supply of micronutrients is also important for the integrity of biological membranes (Rengel, 2004).

When used engine oil is discarded on soil, such as in mechanic workshops in developing countries, the heavy metals can constitute serious environmental hazards not only from the petroleum hydrocarbon introduced into the soil but also from the heavy metals present in the oil. The occurrence of metals in used engine may be as a result of (1) additives used in the production of engine oil (2) wear from engine parts (3) additives in gasoline etc. Other activities that may result to elevated levels of heavy metals in the soil of mechanic workshops include, panel beating, welding and car battery maintenance. The bioremediation of petroleum hydrocarbon introduced into the environment by dumping used engine oil on soil has received some attention (Adelowo et al., 2006; Szewczyk and D1ugon'ski, 2009). Adelekan and Abegunde (2011) studied the concentrations of heavy metals in soil and groundwater at automobile mechanic villages located in Ibadan, Nigeria, and compared the results with guidelines from various countries. Metals considered were $\mathrm{Cd}, \mathrm{Cu}, \mathrm{Pb}, \mathrm{Cr}$ and 
Ni. Evidence of contamination was obvious when results from soil from mechanic villages were compared with those of the control. The values measured in the study were higher than the limits in several cases. It is the intention of this work to investigate the effect of workshop type on the concentration of heavy metals in soils from mechanic workshops around Zaria, Nigeria, as well as to compare the heavy metal concentrations with recommended set limits in a bid to create more awareness of the environmental effects of the activities in mechanic workshops.

\section{MATERIALS AND METHODS}

\section{Soil sample collection}

Soil samples were collected from mechanic workshops (auto and generator mechanic workshops) in and around Zaria. Auto mechanic workshops are usually located by the road side and after a survey of Zaria (enumerating the auto mechanic workshops) the routes indicated in Table 1 where chosen for the various types of workshops. HD, MC and $\mathrm{MM}$ are heavy duty vehicle mechanic workshops (trucks/lorries), motorcycle mechanic workshop and motorcar mechanic workshop respectively. Therefore, as shown in Table 1, six (6) workshops were considered for sampling between Samaru and Kwagila: zero (0) HD, three (3) MC and (3) MM. Three (3) workshops were also considered between Wusasa and Kofan-Doka: zero (0) HD, zero (0) MC and $3 \mathrm{MM}$, and so on. The choice of type of workshop for specific routes was based on the availability and distribution of such mechanic workshops. The map of Zaria showing the area covered is presented in Figure 1. For the generator set mechanic workshops (GEN), since they may not be by the roadside, the area considered (Zaria) was partitioned into Samaru, Kwagila, Gaskiya and Sabo. Soil samples were collected from a minimum of two (2) workshops per partition. A total of nine (9) workshops per type of

Table 1: Distribution of mechanic workshops for soil sample collection.

\begin{tabular}{|c|c|c|c|c|}
\hline Locations & Co-ordinates & \multicolumn{3}{|c|}{ Mechanic workshops } \\
\hline \multirow[t]{2}{*}{ Samaru } & $11^{\circ} 099^{\prime} 41.07{ }^{\prime} \mathrm{N}$ & \multirow{4}{*}{$\begin{array}{l}\text { 0HD } \\
3 \mathrm{MC} \\
3 \mathrm{MM}\end{array}$} & \multirow{6}{*}{$\begin{array}{l}6 \mathrm{HD} \\
0 \mathrm{MC} \\
0 \mathrm{MM}\end{array}$} & \\
\hline & 7³8'39.03'’'E & & & \\
\hline \multirow[t]{2}{*}{ Kwagila (Flyover) } & $11^{\circ} 07^{\prime} 46.07^{\prime \prime} \mathrm{N}$ & & & \\
\hline & $7^{\circ} 42^{\prime} 13.89^{\prime \prime} \mathrm{E}$ & & & \\
\hline \multirow[t]{2}{*}{ Wusasa } & $11^{\circ} 04^{\prime} 35.98^{\prime \prime} \mathrm{N}$ & & & \multirow{3}{*}{$\begin{array}{l}\text { OHD } \\
\text { OMC }\end{array}$} \\
\hline & $7^{\circ} 41^{\prime} 07.30^{\prime \prime} \mathrm{E}$ & & & \\
\hline \multirow[t]{2}{*}{ Kofan-Doka(Zaria city gate) } & $11^{\circ} 04^{\prime} 44.32^{\prime \prime} \mathrm{N}$ & \multirow{4}{*}{$\begin{array}{l}1 \mathrm{HD} \\
3 \mathrm{MC} \\
3 \mathrm{MM}\end{array}$} & & \\
\hline & $7^{\circ} 42^{\prime} 36.78^{\prime \prime} \mathrm{E}$ & & & $3 \mathrm{MM}$ \\
\hline \multirow[t]{2}{*}{ SunSeed Industry (Jos road) } & $11^{\circ} 04^{\prime} 43.57^{\prime \prime} \mathrm{N}$ & & & \\
\hline & $7^{\circ} 45^{\prime} 03.06^{\prime} \mathrm{E}$ & & & \\
\hline \multirow[t]{2}{*}{ Muchia Roundabout (Sabon Gari) } & $11^{\circ} 07^{\prime} 06.17^{\prime \prime} \mathrm{N}$ & \multirow{4}{*}{$\begin{array}{l}\text { OHD } \\
3 \mathrm{MC} \\
0 \mathrm{MM}\end{array}$} & & \\
\hline & $7^{\circ} 43^{\prime} 57.099^{\prime} \mathrm{E}$ & & & \\
\hline \multirow[t]{2}{*}{ Lagos street (Sabon Gari) } & $11^{\circ} 06^{\prime} 38.13^{\prime \prime} \mathrm{N}$ & & & \\
\hline & $7^{\circ} 43^{\prime} 41.74^{\prime \prime} \mathrm{E}$ & & & \\
\hline
\end{tabular}

$\mathrm{HD}=$ truck/lorry mechanic workshop, $\mathrm{MC}=$ motorcycle mechanic workshop, $\mathrm{MM}=\overline{\text { motorcar mechanic }}$ workshop. 


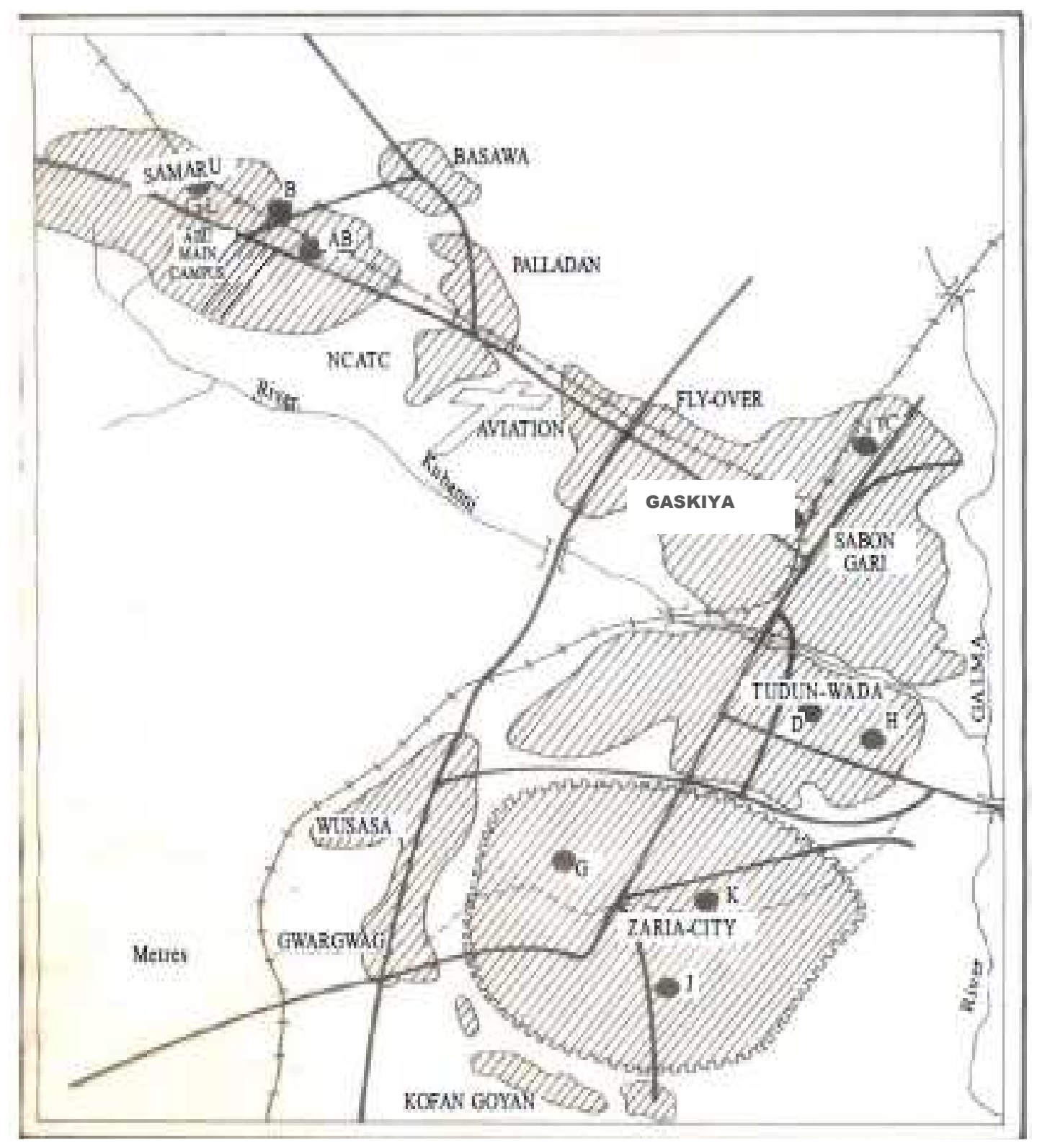

Figure 1: Zaria metropolis showing the area covered.

Modified from Zaria Topographic map and field work 2006.

workshop were considered. Only top soil was considered by digging to a depth of $5 \mathrm{~cm}$. 500 $\mathrm{g}$ of soil from each site was collected in clean plastic containers from a point identified as the centre of activity at the workshop.

Some mechanic workshops, specialized in repairing more than one type of engine, were not considered in this investigation. Soil samples were obtained from mechanic workshops in which only one type of engine amongst MC, MM, HD or GEN was attended to.

Soil sample was also collected from a village farmland (essentially free from petroleum hydrocarbon and inorganic fertilizer) for use as control. 


\section{Sample analysis}

The collected soil samples were dried in an oven at $40{ }^{\circ} \mathrm{C}$ for 72 hours. Samples were then taken for elemental analysis using XRF [MiniPal PW4025, Philips Analytical which is an energy dispersive microprocessor controlled analytical instrument designed for the detection and measurement of elements in a sample (solids, powders and liquids), from sodium to uranium]. The sample for analysis was weighed and ground in an agate mortar and a binder (PVC dissolved in Toluene) was added to the sample, carefully mixed and pressed in a hydraulic press into a pellet. The pellet was loaded in the sample chamber of the spectrometer and voltage $(30 \mathrm{kV}$ maximum) and a current ( $1 \mathrm{~mA}$ maximum) is applied to produce the X-ray to excite the sample for a preset time (10 mins in this case). The spectrum from the sample was then analyzed to determine the concentration of the elements in the sample (Maqsood and Iqbal, 2010).

\section{Statistical analysis}

One-way ANOVA, using Microsoft excel, was used to check the dependence of heavy metal concentration on mechanic workshop type at $95 \%$ confidence interval.

\section{RESULTS}

Table 2 presents the USEPA limits used for comparison: as shown, the metals of interest are Arsenic (As), Cadmium (Cd),
Copper $(\mathrm{Cu})$, Lead $(\mathrm{Pb})$, Mercury $(\mathrm{Hg})$, Nickel (Ni), Selenium (Se) and Zinc (Zn). Table 3 presents the elemental analysis of the uncontaminated soil sample: $\mathrm{As}, \mathrm{Cd}, \mathrm{Pb}, \mathrm{Hg}$ and $\mathrm{Se}$ fell below detection level. The concentrations of the detected heavy metals were within safe limits (when compared with Table 2). The elemental analysis of soil obtained from mechanic workshops is presented in Tables 4 and 5 for motorcycle/motorcar and lorry/generator mechanic workshops respectively: the results indicated a general increase in the \% composition of metals in the soil of mechanic workshops. In addition, $\mathrm{Cd}, \mathrm{Hg}$ and $\mathrm{Se}$ were below detection levels. Table 6 presents the $\%$ number of samples with concentrations of the indicated heavy metals in excess of the USEPA limits for the various types of mechanic workshops considered: for $\mathrm{Ni}, \mathrm{Cu}$, $\mathrm{Zn}, \mathrm{Pb}$ and $\mathrm{As}$ this ranged from $0.00-$ $33.33 \%, 11.11-88.89 \%, 33.33-77.78 \%$, $88.89-100.00 \%$ and $0.00-33.33 \%$ respectively. The results of the statistical analysis using One-way ANOVA at 95\% confidence interval are presented in Table 7: the $P$-values for $\mathrm{Ni}, \mathrm{Cu}, \mathrm{Zn}$ and $\mathrm{Pb}$ (on testing the null hypothesis of no effect from type of mechanic workshop on their composition) were found to be $0.001398,0.003319$, 0.075762 and 0.294605 respectively.

Table 2: Standards for the use or disposal of sewage sludge-pollutant concentrations.

\begin{tabular}{lcc}
\hline Pollutant & $\begin{array}{c}\text { Monthly average concentration } \\
\text { (milligrams per kilogram) }\end{array}$ & $\begin{array}{c}\text { Percentage } \\
\text { composition }\end{array}$ \\
\hline Arsenic & 41 & 0.0041 \\
Cadmium & 39 & 0.0039 \\
Copper & 1500 & 0.1500 \\
Lead & 300 & 0.0300 \\
Mercury & 17 & 0.0000 \\
Nickel & 420 & 0.0420 \\
Selenium & 100 & 0.0100 \\
Zinc & 2800 & 0.2800 \\
\hline
\end{tabular}




\section{A. O. AMEH et al. /Int. J. Biol. Chem. Sci. 5(5): 2103-2113, 2011}

Table 3: The elemental analysis of used engine oil uncontaminated soil sample (farmland soil).

\begin{tabular}{llllllllllllllllllll}
\hline Element & $\mathbf{S}$ & $\mathbf{K}$ & $\mathbf{C a}$ & $\mathbf{T i}$ & $\mathbf{V}$ & $\mathbf{C r}$ & $\mathbf{M n}$ & $\mathbf{F e}$ & $\mathbf{N i}$ & $\mathbf{C u}$ & $\mathbf{Z n}$ & $\mathbf{R b}$ & $\mathbf{S r}$ & $\mathbf{Y}$ & $\mathbf{Z r}$ & $\mathbf{R u}$ & $\mathbf{O s}$ & $\mathbf{E u}$ \\
\hline \% composition & 0.21 & 4.18 & 0.41 & 1.55 & 0.05 & 0.03 & 0.06 & 4.71 & 0.01 & 0.08 & 0.01 & 0.05 & 0.03 & 0.04 & 0.38 & 0.49 & 0.02 & 0.05 \\
\hline
\end{tabular}

Table 4: Elemental analysis of UEO contaminated soil from motorcycle and motorcar mechanic workshops.

\begin{tabular}{|c|c|c|c|c|c|c|c|c|c|c|c|c|c|c|c|c|c|c|}
\hline & MC1 & MC2 & MC3 & MC4 & MC5 & MC6 & MC7 & MC8 & MC9 & MM1 & MM2 & MM3 & MM4 & MM5 & MM6 & MM7 & MM8 & MM9 \\
\hline \multicolumn{19}{|c|}{ Percentage composition } \\
\hline $\mathbf{S}$ & 2.30 & 1.60 & 1.50 & 0.10 & 3.50 & 1.00 & 1.00 & 1.60 & 0.60 & 1.00 & 1.60 & 0.96 & 0.88 & 1.50 & 1.40 & 1.10 & 0.83 & 1.30 \\
\hline $\mathbf{K}$ & 5.50 & 4.77 & 3.51 & 4.19 & 3.22 & 3.93 & 4.15 & 5.14 & 5.50 & 3.74 & 3.95 & 5.20 & 3.49 & 4.95 & 5.77 & 2.29 & 3.37 & 5.06 \\
\hline $\mathbf{C a}$ & 6.29 & 6.93 & 3.61 & 2.79 & 3.86 & 8.35 & 4.18 & 6.65 & 5.15 & 8.11 & 4.08 & 6.93 & 2.64 & 5.69 & 4.17 & 3.91 & 8.75 & 4.93 \\
\hline $\mathbf{T i}$ & 1.69 & 1.64 & 1.29 & 1.99 & 1.53 & 1.60 & 1.69 & 1.50 & 1.55 & 1.75 & 1.84 & 1.75 & 1.46 & 1.81 & 1.74 & 1.80 & 1.54 & 1.90 \\
\hline $\mathbf{V}$ & 0.05 & 0.05 & 0.06 & 0.08 & 0.05 & 0.06 & 0.07 & 0.04 & 0.05 & 0.06 & 0.06 & 0.04 & 0.05 & 0.05 & 0.05 & 0.08 & 0.06 & 0.06 \\
\hline $\mathrm{Cr}$ & 0.06 & 0.08 & 0.06 & 0.06 & 0.05 & 0.07 & 0.08 & 0.04 & 0.05 & 0.06 & 0.07 & 0.05 & 0.04 & 0.04 & 0.04 & 0.06 & 0.05 & 0.05 \\
\hline Mn & 0.15 & 0.19 & 0.15 & 0.13 & 0.16 & 0.19 & 0.21 & 0.14 & 0.17 & 0.11 & 0.19 & 0.12 & 0.09 & 0.16 & 0.1 & 0.16 & 0.11 & 0.15 \\
\hline $\mathrm{Fe}$ & 11.5 & 17.2 & 17.82 & 18.21 & 12.24 & 21.9 & 21.89 & 13.3 & 23.27 & 14.82 & 19.42 & 12.5 & 14.05 & 11.8 & 11.2 & 21.58 & 17.6 & 13.2 \\
\hline $\mathbf{N i}$ & 0.05 & 0.07 & 0.10 & 0.03 & 0.02 & 0.04 & 0.04 & 0.03 & 0.04 & 0.02 & 0.02 & 0.02 & 0.02 & 0.02 & 0.02 & 0.02 & 0.02 & 0.00 \\
\hline $\mathrm{Cu}$ & 0.09 & 0.14 & 0.14 & 0.13 & 0.11 & 0.14 & 0.17 & 0.08 & 0.10 & 0.18 & 0.18 & 0.14 & 0.10 & 0.12 & 0.14 & 0.14 & 0.10 & 0.15 \\
\hline $\mathbf{Z n}$ & 0.27 & 0.33 & 0.19 & 0.32 & 0.23 & 0.40 & 0.38 & 0.24 & 0.35 & 0.28 & 0.56 & 0.19 & 0.13 & 0.17 & 0.20 & 0.16 & 0.21 & 0.31 \\
\hline $\mathbf{R b}$ & 0.10 & 0.15 & 0.08 & 0.14 & 0.04 & 0.12 & 0.13 & 0.12 & 0.17 & 0.07 & 0.09 & 0.08 & 0.04 & 0.07 & 0.08 & 0.05 & 0.06 & 0.09 \\
\hline $\mathrm{Sr}$ & 0.11 & 0.15 & 0.06 & 0.09 & 0.04 & 0.15 & 0.11 & 0.14 & 0.14 & 0.09 & 0.07 & 0.07 & 0.03 & 0.07 & 0.06 & 0.04 & 0.05 & 0.06 \\
\hline $\mathbf{Y}$ & 0.10 & 0.15 & 0.08 & 0.12 & 0.05 & 0.14 & 0.12 & 0.10 & 0.12 & 0.06 & 0.06 & 0.05 & 0.04 & 0.06 & 0.06 & 0.05 & 0.05 & 0.06 \\
\hline
\end{tabular}


A. O. AMEH et al. / Int. J. Biol. Chem. Sci. 5(5): 2103-2113, 2011

\begin{tabular}{|c|c|c|c|c|c|c|c|c|c|c|c|c|c|c|c|c|c|c|}
\hline $\mathbf{Z r}$ & 0.96 & 1.18 & 0.74 & 1.03 & 0.45 & 1.03 & 1.02 & 0.81 & 0.75 & 0.56 & 0.54 & 0.59 & 0.47 & 0.64 & 0.61 & 0.63 & 0.43 & 0.71 \\
\hline $\mathbf{R u}$ & 1.74 & 2.77 & 1.30 & 1.76 & 0.75 & 2.30 & 2.11 & 1.48 & 1.90 & 0.96 & 1.20 & 0.95 & 0.61 & 0.87 & 0.90 & 0.68 & 0.90 & 0.92 \\
\hline Ba & 0.10 & 0.24 & 0.10 & 0.10 & 0.10 & 0.20 & 0.20 & 0.21 & 0.23 & 0.25 & 0.34 & 0.27 & 0.10 & 0.17 & 0.17 & 0.10 & 0.10 & 0.24 \\
\hline Os & 0.00 & 0.00 & 0.00 & 0.00 & 0.00 & 0.00 & 0.00 & 0.00 & 0.00 & 0.00 & 0.00 & 0.00 & 0.00 & 0.00 & 0.00 & 0.01 & 0.00 & 0.00 \\
\hline $\mathbf{E u}$ & 0.00 & 0.00 & 0.10 & 0.00 & 0.08 & 0.00 & 0.00 & 0.00 & 0.06 & 0.00 & 0.00 & 0.07 & 0.10 & 0.00 & 0.00 & 0.00 & 0.00 & 0.09 \\
\hline $\mathbf{Y b}$ & 0.00 & 0.00 & 0.00 & 0.00 & 0.00 & 0.00 & 0.06 & 0.00 & 0.00 & 0.00 & 0.02 & 0.00 & 0.01 & 0.00 & 0.00 & 0.00 & 0.00 & 0.00 \\
\hline $\mathbf{R e}$ & 0.00 & 0.09 & 0.02 & 0.00 & 0.00 & 0.00 & 0.00 & 0.02 & 0.00 & 0.00 & 0.00 & 0.05 & 0.01 & 0.03 & 0.02 & 0.01 & 0.04 & 0.00 \\
\hline $\mathbf{P b}$ & 0.04 & 0.08 & 0.09 & 0.14 & 0.05 & 0.92 & 0.07 & 0.00 & 0.06 & 0.17 & 0.41 & 0.18 & 0.06 & 0.05 & 0.10 & 0.15 & 0.10 & 0.13 \\
\hline Th & 0.00 & 0.00 & 0.00 & 0.00 & 0.00 & 0.00 & 0.00 & 0.00 & 0.00 & 0.00 & 0.00 & 0.00 & 0.00 & 0.00 & 0.00 & 0.63 & 0.12 & 0.15 \\
\hline As & 0.00 & 0.00 & 0.00 & 0.00 & 0.00 & 0.00 & 0.00 & 0.00 & 0.00 & 0.00 & 0.00 & 0.00 & 0.00 & 0.00 & 0.00 & 0.00 & 0.00 & 0.00 \\
\hline $\mathrm{Nb}$ & 0.00 & 0.00 & 0.00 & 0.00 & 0.00 & 0.00 & 0.00 & 0.00 & 0.00 & 0.00 & 0.00 & 0.00 & 0.00 & 0.00 & 0.00 & 0.00 & 0.00 & 0.00 \\
\hline
\end{tabular}

Table 5: Elemental analysis of UEO contaminated soil from truck/lorry and generator set mechanic workshops.

\begin{tabular}{|c|c|c|c|c|c|c|c|c|c|c|c|c|c|c|c|c|c|c|}
\hline & HD1 & HD2 & HD3 & HD4 & HD5 & HD6 & HD7 & HD8 & HD9 & GEN1 & GEN2 & GEN3 & GEN4 & GEN5 & GEN6 & GEN7 & GEN8 & GEN9 \\
\hline \multicolumn{19}{|c|}{ Percentage composition } \\
\hline $\mathbf{S}$ & 0.60 & 1.20 & 0.80 & 0.60 & 0.89 & 1.90 & 1.80 & 1.57 & 2.00 & 1.10 & 1.10 & 1.30 & 1.50 & 2.00 & 1.60 & 1.60 & 1.40 & 0.87 \\
\hline $\mathbf{K}$ & 6.90 & 7.28 & 5.71 & 3.49 & 2.67 & 5.96 & 3.74 & 5.03 & 4.01 & 5.05 & 5.34 & 4.05 & 4.11 & 5.97 & 3.49 & 3.52 & 5.38 & 5.56 \\
\hline $\mathrm{Ca}$ & 3.45 & 6.99 & 2.42 & 3.69 & 4.90 & 5.56 & 4.21 & 4.01 & 4.11 & 5.09 & 7.53 & 11.90 & 9.59 & 2.35 & 6.37 & 9.34 & 4.33 & 6.01 \\
\hline $\mathbf{T i}$ & 2.27 & 2.13 & 1.83 & 1.85 & 1.38 & 2.13 & 1.56 & 2.05 & 1.07 & 1.76 & 1.98 & 1.76 & 1.93 & 0.92 & 2.67 & 1.64 & 1.73 & 1.46 \\
\hline $\mathbf{V}$ & 0.09 & 0.07 & 0.06 & 0.05 & 0.06 & 0.08 & 0.06 & 0.06 & 0.04 & 0.05 & 0.05 & 0.05 & 0.06 & 0.03 & 0.10 & 0.05 & 0.07 & 0.03 \\
\hline $\mathbf{C r}$ & 0.09 & 0.06 & 0.06 & 0.07 & 0.06 & 0.08 & 0.09 & 0.08 & 0.05 & 0.05 & 0.05 & 0.06 & 0.06 & 0.06 & 0.06 & 0.09 & 0.06 & 0.06 \\
\hline Mn & 0.11 & 0.21 & 0.09 & 0.19 & 0.11 & 0.20 & 0.12 & 0.13 & 0.39 & 0.15 & 0.18 & 0.17 & 0.02 & 0.06 & 0.44 & 0.24 & 0.19 & 0.12 \\
\hline \multicolumn{19}{|c|}{2109} \\
\hline
\end{tabular}


A. O. AMEH et al. / Int. J. Biol. Chem. Sci. 5(5): 2103-2113, 2011

\begin{tabular}{|c|c|c|c|c|c|c|c|c|c|c|c|c|c|c|c|c|c|c|}
\hline $\mathbf{F e}$ & 17.8 & 20.30 & 10.50 & 22.67 & 18.83 & 21.10 & 22.42 & 19.65 & 13.56 & 10.00 & 12.20 & 13.10 & 17.10 & 12.46 & 20.56 & 24.81 & 18.46 & 11.80 \\
\hline $\mathbf{N i}$ & 0.04 & 0.03 & 0.04 & 0.03 & 0.02 & 0.06 & 0.02 & 0.02 & 0.05 & 0.03 & 0.02 & 0.02 & 0.04 & 0.02 & 0.02 & 0.02 & 0.02 & 0.02 \\
\hline $\mathrm{Cu}$ & 0.14 & 0.23 & 0.26 & 0.15 & 0.17 & 0.50 & 0.16 & 0.20 & 0.25 & 0.13 & 0.14 & 0.13 & 0.17 & 0.18 & 0.14 & 0.18 & 0.12 & 0.14 \\
\hline Zn & 0.17 & 0.33 & 0.15 & 0.27 & 0.20 & 0.39 & 0.30 & 0.24 & 0.22 & 0.20 & 0.37 & 0.49 & 0.53 & 0.18 & 0.42 & 0.62 & 0.28 & 0.29 \\
\hline $\mathbf{R b}$ & 0.23 & 0.00 & 0.19 & 0.14 & 0.08 & 0.21 & 0.11 & 0.16 & 0.12 & 0.07 & 0.09 & 0.07 & 0.07 & 0.08 & 0.07 & 0.05 & 0.11 & 0.06 \\
\hline $\mathbf{S r}$ & 0.12 & 0.17 & 0.10 & 0.10 & 0.06 & 0.15 & 0.09 & 0.09 & 0.12 & 0.08 & 0.09 & 0.10 & 0.10 & 0.03 & 0.04 & 0.07 & 0.07 & 0.04 \\
\hline $\mathbf{Y}$ & 0.18 & 0.21 & 0.12 & 0.13 & 0.09 & 0.17 & 0.09 & 0.12 & 0.10 & 0.08 & 0.07 & 0.06 & 0.08 & 0.04 & 0.04 & 0.05 & 0.07 & 0.07 \\
\hline $\mathbf{Z r}$ & 1.29 & 0.95 & 0.90 & 1.15 & 0.80 & 1.49 & 0.75 & 1.12 & 1.00 & 0.77 & 0.80 & 0.41 & 0.98 & 0.22 & 0.41 & 0.38 & 0.39 & 0.39 \\
\hline $\mathbf{R u}$ & 3.13 & 2.99 & 2.05 & 2.20 & 1.56 & 3.14 & 1.50 & 2.10 & 2.01 & 1.23 & 1.20 & 0.91 & 1.50 & 0.81 & 0.80 & 0.84 & 0.85 & 1.19 \\
\hline $\mathbf{B a}$ & 0.25 & 0.42 & 0.20 & 0.23 & 0.17 & 0.43 & 0.30 & 0.31 & 0.35 & 0.19 & 0.20 & 0.20 & 0.22 & 0.07 & 0.00 & 0.20 & 0.19 & 0.10 \\
\hline Os & 0.00 & 0.00 & 0.00 & 0.00 & 0.00 & 0.00 & 0.00 & 0.00 & 0.00 & 0.00 & 0.00 & 0.00 & 0.00 & 0.00 & 0.00 & 0.00 & 0.00 & 0.00 \\
\hline $\mathbf{E u}$ & 0.00 & 0.10 & 0.00 & 0.10 & 0.00 & 0.00 & 0.10 & 0.00 & 0.10 & 0.07 & 0.04 & 0.06 & 0.20 & 0.15 & 0.10 & 0.20 & 0.10 & 0.08 \\
\hline $\mathbf{Y b}$ & 0.0 & 0.00 & 0.00 & 0.00 & 0.01 & 0.00 & 0.03 & 0.00 & 0.00 & 0.00 & 0.00 & 0.00 & 0.00 & 0.00 & 0.00 & 0.00 & 0.00 & 0.00 \\
\hline $\mathbf{R e}$ & 0.03 & 0.04 & 0.03 & 0.03 & 0.03 & 0.07 & 0.00 & 0.03 & 0.03 & 0.03 & 0.00 & 0.00 & 0.00 & 0.05 & 0.00 & 0.00 & 0.00 & 0.00 \\
\hline $\mathbf{P b}$ & 0.18 & 0.30 & 0.19 & 0.39 & 0.16 & 0.58 & 0.26 & 0.25 & 0.28 & 0.17 & 0.12 & 0.12 & 0.51 & 0.29 & 0.30 & 0.40 & 0.22 & 0.15 \\
\hline Th & 0.20 & 0.00 & 0.00 & 0.00 & 0.00 & 0.00 & 0.00 & 0.00 & 0.00 & 0.00 & 0.00 & 0.00 & 0.00 & 0.00 & 0.00 & 0.00 & 0.00 & 0.00 \\
\hline As & 0.00 & 0.00 & 0.01 & 0.00 & 0.00 & 0.00 & 0.00 & 0.00 & 0.00 & 0.01 & 0.00 & 0.00 & 0.02 & 0.00 & 0.00 & 0.00 & 0.00 & 0.01 \\
\hline $\mathrm{Nb}$ & 0.00 & 0.00 & 0.00 & 0.00 & 0.00 & 0.08 & 0.00 & 0.00 & 0.00 & 0.00 & 0.00 & 0.00 & 0.00 & 0.00 & 0.00 & 0.00 & 0.00 & 0.00 \\
\hline
\end{tabular}


Table 6: \% of samples size in excess of US EPA limit for various elements.

\begin{tabular}{lcccc}
\hline Elements & \multicolumn{4}{c}{ \% of number of samples exceeding US EPA standard } \\
\cline { 2 - 5 } & MC & MM & HD & GEN \\
\hline & & & & \\
$\mathbf{N i}$ & 33.33 & 0.00 & 22.22 & 0.00 \\
$\mathbf{C u}$ & 11.11 & 33.33 & 88.89 & 33.33 \\
$\mathbf{Z n}$ & 44.44 & 33.33 & 33.33 & 77.78 \\
$\mathbf{P b}$ & 88.89 & 100.00 & 100.00 & 100.00 \\
$\mathbf{A s}$ & 0.00 & 0.00 & 11.11 & 33.33 \\
\hline
\end{tabular}

$\mathrm{HD}=$ truck/lorry mechanic workshop, $\mathrm{MC}=$ motorcycle mechanic workshop, $\mathrm{MM}=$ motorcar mechanic workshop, GEN = generator set mechanic workshop.

Table 7: One-Way ANOVA for the composition of $\mathrm{Ni}, \mathrm{Cu}, \mathrm{Zn}$ and $\mathrm{Pb}$ content of soil from mechanic workshops.

\begin{tabular}{ll}
\hline Elements & P-value \\
\hline $\mathrm{Ni}$ & 0.001398 \\
$\mathrm{Cu}$ & 0.003319 \\
$\mathrm{Zn}$ & 0.075762 \\
$\mathrm{~Pb}$ & 0.294605 \\
\hline
\end{tabular}

\section{DISCUSSION}

\section{Elemental analysis}

The increase in the composition of metal in soil from mechanic workshops, which is in agreement with Amusan et al. (2005) and Leke et al. (2011), may be attributed to the availability of metal containing wastes in mechanic workshops which eventually end up in the soil. The composition of $\mathrm{Ni}, \mathrm{Cr}, \mathrm{Pb}, \mathrm{Cu}$ were far higher than the values obtained by Leke et al. (2011) who carried out similar investigations in Makurdi, Nigeria.

Whereas $\mathrm{Cd}$ was detected in soil samples from auto mechanic workshops by Leke et al. (2011), it fell below detection level in this work. This may possibly be as result of the geographic location, age of workshop, waste disposal habits as well as the method used in the elemental analyses. Of the 36 samples analyzed in Tables 4 and 5, Arsenic (As) was detected in only four (4) samples (HD3, GEN1, GEN4 and GEN9), all of which were above the set limit of Table 2. As shown in Table 6, many of the samples had concentrations of the regulated elements in excess of the USEPA limits, lead $(\mathrm{Pb})$ particularly: apart from $\mathrm{MC} 8$ for which $\mathrm{Pb}$ was not detected, all other samples recorded $\mathrm{Pb}$ concentration in excess of USEPA limit.

\section{Statistical analysis}

For Copper, the null hypothesis of no effect of source of contaminated soil is rejected $(\mathrm{P}<0.05)$ : it appears that the Copper content of the soil from mechanic workshops is affected by the type of machines treated in the workshop. Similar deduction can be made for nickel. Copper and nickel are used in the manufacture of engine components such as sparkplugs. The composition of copper and nickel for all samples considered ranged between $800-1800 \mathrm{mg} / \mathrm{kg}$ and $0-700 \mathrm{mg} / \mathrm{kg}$ respectively and were found to be higher than 1.48 to $476.0 \mathrm{mg} / \mathrm{kg}$ and $2.0-25.0 \mathrm{mg} / \mathrm{kg}$ as respectively reported by Adelekan and Abegunde (2011). Leke et al. (2011) reported an average value of $51.04 \pm 40.16 \mathrm{mg} / \mathrm{kg}$ for $\mathrm{Cu}$ and $04.20 \pm 00.96 \mathrm{mg} / \mathrm{kg}$ for $\mathrm{Ni}$. 
For Zinc $(\mathrm{Zn})$ and lead $(\mathrm{Pb})$ with $\mathrm{P}$ values $>0.05$, the null hypothesis of no effect from type of mechanic workshop on the composition cannot be rejected: the composition of these elements in the contaminated soils appears not to be affected by type of workshop. Additives such as zinc diaryl and zinc dithiophosphate ( $\mathrm{Lu}$ and Kaplan, 2008) are usually added in the formulation of engine oil as such is expected to be present in soil when used engine oil is dumped on it. Lead is a component of solder and storage batteries: soil contamination may take place in all types of mechanic workshops (Technical Workshop Group, 2001). The composition of zinc and lead for all samples considered ranged between 1300 - 6200 $\mathrm{mg} / \mathrm{kg}$ and $0-5800 \mathrm{mg} / \mathrm{kg}$ respectively. For lead, this range was lower than that reported by Adelekan and Abegunde (2011): 18.25 $15100 \mathrm{mg} / \mathrm{kg}$ whereas Leke et al. (2011) reported an average of $37.64 \pm 31.62 \mathrm{mg} / \mathrm{kg}$.

\section{Conclusion}

Heavy metal contents of soil from motorcycle, motorcar, truck/lorry and generator set mechanic workshops were compared. Soils from all types of mechanic workshops were found to contain elevated levels of metals when compared to soil samples free from mechanic activities. Generally, the cadmium, mercury, and selenium content of soil from the workshops were within safe limits. The $\mathrm{Zn}, \mathrm{Cu}$ and $\mathrm{Pb}$ contents of many of the samples analyzed were in excess of regulatory set limits. It appears that the $\mathrm{Zn}$ and $\mathrm{Pb}$ content of soil from mechanic workshops was not a function of the workshop type, whereas the nickel and copper contents appear to be dependent on workshop type. In this light, education and legislations on management of wastes in the workshops should be intensified to forestall the effects of waste related problems on the environment. Modern waste disposal facilities should be acquired by relevant authorities and appropriate waste disposal sites be chosen to avoid the injurious effects of indiscriminate disposal of wastes.

\section{ACKNOWLEDGEMENTS}

Authors thank the Science and Technology Education Post-Basic (STEP-B) Innovators of Tomorrow (IOT) and the University Board of Research (Ahmadu Bello University, Zaria) for their financial support.

\section{REFERENCES}

Adelekan BA, Abegunde KD. 2011. Heavy metals contamination of soil and groundwater at automobile mechanic villages in Ibadan, Nigeria. International Journal of the Physical Sciences, 6(5): 1045-1058.

Adelowo OO, Alagbe SO, Ayandele AA. 2006. Time-dependent stability of used engine oil degradation by cultures of Pseudomonas fragi and Achromobacter aerogens. African Journal of Biotechnology, 5(24): 2476- 2479.

Amusan AA, Ige DV, Olawale RJ. 2005. Human Ecology. Environmental Science Journal, 17: 167 - 171.

Appenroth KJ. 2010. What are "heavy metals" in Plant Sciences? Acta Physiol Plant, 32: 615-619.

Granero S, Domingo JL. 2002. Levels of metals in soils of Alcala de Henares, Spain: human health risks. Environ. Int., 28: 159 - 164.

Kovacs E, Nyitrai P, Czovek P, Ovari M, Keresztes A. 2009. Investigation into the mechanism of stimulation by lowconcentration stressors in barley seedlings. J. Plant Physiol., 166: 72-79.

Leke L, Akaahan TJ, Simon A. 2011. Heavy Metals in Soils of auto- mechanic shops and refuse dumpsites in Makurdi Nigeria. J. Appl. Sci. Environ. Manage, 15(1): 207-210.

Li XD, Poon CS, Liu PS. 2001. Heavy metal contamination of urban soils and street dusts in Hong Kong. Appl. Geochem, 16: 1361-1368.

Ljung K, Selinus O, Otabbong E. 2006. Metals in soils of children's urban environments in the small northern European city of Uppsala. Sci. Total Environ., 366: 749 - 759. 
Lu S-T, Kaplan IR. 2008. Characterization of Motor Lubricating Oils and Their OilWater Partition. Environmental Forensics, 9(4): 295 - 309 .

Madrid L, Diaz-Barrientos E, Madrid F. 2002. Distribution of heavy metal contents of urban soils in parks of Seville. Chemosphere, 49: 1301-1308.

Mielke HW, Gonzales CR, Smith MK, Mielke PW. 1998. The urban environment and children's health: Soils as an integrator of lead, zinc, cadmium in New Orleans, Louisiana, U.S.A. Environ. Res., 81: 117129.

Nyitrai P, Mayer M, Ovari M, Keresztes A. 2007. Involvement of the phosphoinositide signalling pathway in the anti-senescence effect of lowconcentration stressors on detached barley leaves. Plant Biol., 9: 420-426.

Rengel Z. 2004. Heavy metals as essential nutrients. In Heavy Metal Stress in Plants (2nd edn), Prasad MNV (ed). Springer: Berlin; 271-294.

Sanchez-Camazano M, Sanchez-Martin MJ, Lorenzo LF. 1994. Lead and cadmium in soils and vegetables from urban gardens of Salamaca (Spain). Sci. Total Environ., 146/147: 163 - 168 .

Sastre J, Sahuquillo A, Vidal M, Rauret G. 2002. Determination of $\mathrm{Cd}, \mathrm{Cu}, \mathrm{Pb}$ and $\mathrm{Zn}$ in environmental samples: microwave assisted total digestion versus aqua regia and nitric acid extraction. Anal. Chim. Acta., 462(1): 59-72.

Sieghardt M, Mursch-Radlgruber E, Paoletti E, Couenberg E, Dimitrakopoulus A, Rego F, Hatzistathis A, Barfoed Randrup T. 2005. Urban Forests and Trees. Springer: Berlin.

Szewczyk R, Dlugon'ski J. 2009. Pentachlorophenol and spent engine oil degradation by Mucor ramosissimus. International Biodeterioration \& Biodegradation, 63: 123-129.

Technical Workshop Group. 2001. Draft of Technical Guidelines on environmentally sound management of Lead-Acid Battery Wastes, Eighteenth session.

Vespa M, lanson M, Manceau A. 2010. Natural attenuation of zinc pollution in smelter-affected soil. Environmental Science and Technology, 44: 7814-7820.

Weber J, Karczewska A. 2004. Biogeochemical processes and the role of heavy metals in the environment. Geoderma, 122: 105-324.

Maqsood A, Iqbal K. 2010. Materials Characterization by Non-Destructive Methods. Journal of the Pakistan Materials Society, 4(1): 31 - 38 . 